\title{
Human rhabdomyosarcoma cells express functional pituitary and gonadal sex hormone receptors: Therapeutic implications
}

\author{
AGATA PONIEWIERSKA-BARAN ${ }^{1,2}$, GABRIELA SCHNEIDER $^{1}$, WENYUE SUN $^{3}$, \\ AHMED ABDELBASET-ISMAIL ${ }^{1}$, FREDERIC G. BARR ${ }^{4}$ and MARIUSZ Z. RATAJCZAK ${ }^{1,3}$ \\ ${ }^{1}$ Stem Cell Institute at James Graham Brown Cancer Center, University of Louisville, Louisville, KY, USA; \\ ${ }^{2}$ Department of Physiology, Pomeranian Medical University, Szczecin; ${ }^{3}$ Department of Regenerative Medicine , \\ Warsaw Medical University, Warsaw, Poland; ${ }^{4}$ Laboratory of Pathology, National Cancer Institute, Bethesda, MD, USA
}

Received December 15, 2015; Accepted January 20, 2016

DOI: 10.3892/ijo.2016.3439

\begin{abstract}
Evidence has accumulated that sex hormones play an important role in several types of cancer. Because they are also involved in skeletal muscle development and regeneration, we were therefore interested in their potential involvement in the pathogenesis of human rhabdomyosarcoma (RMS), a skeletal muscle tumor. In the present study, we employed eight RMS cell lines (three fusion positive and five fusion negative RMS cell lines) and mRNA samples obtained from RMS patients. The expression of sex hormone receptors was evaluated by RT-PCR and their functionality by chemotaxis, adhesion and direct cell proliferation assays. We report here for the first time that follicle-stimulating hormone (FSH) and luteinizing hormone (LH) receptors are expressed in established human RMS cell lines as well as in primary tumor samples isolated from RMS patients. We also report that human RMS cell lines responded both to pituitary and gonadal sex hormone stimulation by enhanced proliferation, chemotaxis, cell adhesion and phosphorylation of MAPKp42/44 and AKT. In summary, our results indicate that sex hormones are involved in the pathogenesis and progression of RMS, and therefore, their therapeutic application should be avoided in patients that have been diagnosed with RMS.
\end{abstract}

\section{Introduction}

Rhabdomyosarcoma (RMS) is the most common soft-tissue sarcoma of adolescence and childhood and as reported accounts for $5 \%$ of all malignant tumors in patients under 15 years of age $(1,2)$. It occurs also in older patients, and the

Correspondence to: Professor Mariusz Z. Ratajczak, Stem Cell Institute at James Graham Brown Cancer Center, University of Louisville, 500 S. Floyd Street, Room 107, Louisville, KY 40202, USA

E-mail:mzrata01@louisville.edu

Key words: rhabdomyosarcoma, follicle-stimulating hormone, luteinizing hormone, androgen, proliferation, metastasis median age at diagnosis for all 2,600 analyzed RMS cases (birth through 96 years) was 16 years (3). RMS belongs to the family of so-called 'small round blue tumor cells', which often infiltrate bone marrow (BM) and on BM smears may sometimes be misdiagnosed as acute leukemia cells (4). There are two major histological subtypes of this tumor: alveolar rhabdomyosarcoma (ARMS) and embryonal rhabdomyosarcoma (ERMS). ARMS is associated with more aggressive behavior and a worse prognosis than ERMS (5).

At the molecular level, ARMS is characterized by the $t(2 ; 13)(q 35 ; q 14)$ translocation in $70 \%$ of cases and the variant $\mathrm{t}(1 ; 13)(\mathrm{p} 36 ; \mathrm{q} 14)$ in a smaller percentage of cases $(6)$. These translocations disrupt the $P A X 3$ and $P A X 7$ genes on chromosomes 2 and 1, respectively, and the FOXO1 gene on chromosome 13, generating PAX3-FOXOI and PAX7-FOXOI fusion genes. The resulting fusion proteins, PAX3-FOXO1 and PAX7-FOXO1, have enhanced transcriptional activity compared with wild-type PAX3 and PAX7 and are postulated to play a role in cell survival and dysregulation of the cell cycle in ARMS (7). Since there are also ARMS cases that are fusion-negative and have a better outcome than ARMS cases that are fusion-negative, it has recently been proposed that RMS be classified into fusion-positive (PAX3-FOXO1 and $P A X 7-F O X O 1)$ and fusion-negative tumors (8).

Both pituitary peptide- and gonadal steroid-based sex hormones play an important role in normal development and tumorigenesis and, thus, we were interested in the role of sex hormones in RMS pathogenesis. First, it is well known that these hormones are involved in both developmental growth and regeneration of skeletal muscles (9-11). For example, skeletal muscle satellite stem cells respond to stimulation by estrogens and androgens $(9,12)$. Second, pediatric sarcomas, including RMS, share several common markers with the germ line-derived cells. For example, RMS cells express several cancer testis antigens (CTAs) $(13,14)$. Moreover, changes in expression of parentally imprinted genes (e.g, $\operatorname{Ig} f 2-\mathrm{H} 19$, Dlkl-Meg3 and $p 57^{K I P 2}$ ) are involved in the pathogenesis of both pediatric sarcomas and germline tumors (15-17). Notably, 150 years ago, Virchow (18) and Conheim (19) proposed the so-called 'embryonic rest' hypothesis of cancer development, in which malignancies may develop from dormant development early embryonic cells or perhaps cells endowed with 
germ line potential residing in adult tissues. Small round blue cell tumors, including RMS, are potential candidates for such malignancies. Interestingly, a recent report demonstrated that the $P A X 7$ gene, which plays an important role in skeletal muscle development, is one of the stem cell markers in germ cells in gonads (20).

We report here that several sex hormone receptors are indeed expressed by RMS cells. Moreover, we demonstrate for the first time that follicle-stimulating hormone (FSH) and luteinizing hormone (LH) receptors are expressed in established human RMS cell lines and, even more importantly, in primary tumor samples isolated from patients. We also found that several human RMS cell lines respond to pituitary and gonadal sex hormone stimulation by enhanced proliferation, chemotaxis, cell adhesion and phosphorylation of MAPKp42/44 and AKT. We conclude that sex hormones are involved in the pathogenesis and progression of RMS, and their therapeutic application should be avoided in patients with RMS.

\section{Materials and methods}

Cell lines. We used several human RMS cell lines (provided by Dr Peter Houghton, Nationwide Children's Cancer Center, Columbus, OH, USA), including both fusion-positive (RH28, RH30 and RH41) and fusion-negative (JR, RD, RH18, RH36 and SMS-CTR) cell lines. All cell lines used in the present study were authenticated by short tandem repeat (STR) analysis. STR profiles were compared with those of the original cell lines, obtained in Dr Peter Houghton's Laboratory, or with published profiles. SMS-CTR and RH36 cells were cultured in Dulbecco's modified Eagle's medium (DMEM) containing $10 \%$ heat-inactivated fetal bovine serum (FBS), $100 \mathrm{U} / \mathrm{ml}$ penicillin and $10 \mu \mathrm{g} / \mathrm{ml}$ streptomycin. All other RMS cells used for experiments were cultured in Roswell Park Memorial Institute (RPMI)-1640 medium, supplemented with $100 \mathrm{IU} / \mathrm{ml}$ penicillin and $10 \mu \mathrm{g} / \mathrm{ml}$ streptomycin in $10 \%$ heat-inactivated FBS. The cells were cultured in a humidified atmosphere at $37^{\circ} \mathrm{C}$ in $5 \% \mathrm{CO}_{2}$ at an initial cell density of $2.5 \times 10^{4}$ cells/flask.

Conventional RT-PCR. Total RNA from various cells was isolated using the RNeasy Mini kit (Qiagen Inc., Valencia CA, USA), including treatment with DNase I (Qiagen). The mRNA was reverse-transcribed with TaqMan Reverse Transcription reagents (Applied Biosystems, Grand Island, NY, USA) according to the manufacturer's instructions. The resulting cDNA fragments were amplified $\left(1\right.$ cycle of $8 \mathrm{~min}$ at $95^{\circ} \mathrm{C}$, 2 cycles of $2 \mathrm{~min}$ at $95^{\circ} \mathrm{C}, 1 \mathrm{~min}$ at $60^{\circ} \mathrm{C}, 1 \mathrm{~min}$ at $72^{\circ} \mathrm{C}$, and subsequently 40 cycles of $30 \mathrm{sec}$ at $95^{\circ} \mathrm{C}, 1 \mathrm{~min}$ at $60^{\circ} \mathrm{C}, 1 \mathrm{~min}$ at $72^{\circ} \mathrm{C}$, and 1 cycle of $10 \mathrm{~min}$ at $72^{\circ} \mathrm{C}$ ) using AmpliTaq Gold polymerase with sequence-specific primers designed using the $\mathrm{NCBI} /$ Primer-BLAST program. One primer in each pair was designed to include an exon-intron boundary: $\beta$-actin: $F, G G$ ATGCAGAAGGAGATCACTG and R, CGATCCACACGGA GTACTTG; hFSHR: F, GCTTCTGAGATCTGTGGAGGTT and R, ACCTCAGTTCAATGGCATTCCT; hLHR: F, GGG CCGCACTCAGAGG and R, AGGGAGGTAGGCAAGTGA TAGTC; hER $\alpha$ : F, AGGTGCCCTACTACCTGGAG and R, CGGTCTTTTCGTATCCCACCT; hER $\beta$ : F, TTTTTGGACA CCCACTCCCC and R, CACCTGTTGAGGAAAGCGAG; hANDR: F, CGACTTCACCGCACCTGATG and R, CTTCT
GTTTCCCTTCAGCGG; hPROGR: F, CGGACACCTT GCCTGAAGTT and R, AGTCCGCTGTCCTTTTCTGG; hPRLR: F, GAGCTTCTTCTCACAGAGCCA and R, AAGT TCACTTCAGGGTTCATGTGG.

Fluorescent staining of the rhabdomyosarcoma cells. RH30 and RD cells were fixed in $4 \%$ paraformaldehyde for $15 \mathrm{~min}$, permeabilized by employing $0.1 \%$ Triton X-100 for $10 \mathrm{~min}$, washed in PBS, preblocked with $2.5 \%$ BSA in PBS, and subsequently stained with antibodies to follicle-stimulating hormone receptor (FSH-R, 1:200, rabbit polyclonal antibody; Santa Cruz Biotechnology, Santa Cruz, CA, USA), luteinizing hormone/choriogonadotropin receptor (LH-R, 1:200, rabbit polyclonal antibody; Santa Cruz Biotechnology), androgen receptor (Ab-2, 1:200, rabbit polyclonal antibody; Thermo Fisher Scientific, Pittsburgh, PA, USA), and estrogen receptor (ER, Ab-11, 1:200, mouse monoclonal IgG antibody; Thermo Fisher Scientific). Staining was performed overnight in $4^{\circ} \mathrm{C}$. Antibodies were diluted in $2.5 \%$ BSA in PBS. Appropriate secondary antibody Texas Red were used for $2 \mathrm{~h}$ at $37^{\circ} \mathrm{C}$ (1:400; Texas Red goat anti-rabbit IgG and Texas Red horse anti-mouse IgG; Vector Laboratories, Inc., Burlingame, CA, USA). In control experiments, cells were stained with secondary antibodies only. The nuclei were labeled with DAPI. The fluorescence images were collected with a confocal laser scanning microscope (FV1000; Olympus).

Chemotaxis assay. Chemotaxis assays were performed in a modified Boyden's chamber with $8-\mu \mathrm{m}$-pore polycarbonate membrane inserts (Costar Transwell; Corning IncorporatedLife Sciences, Lowell, MA, USA) as previously described. In brief, cells detached with $0.25 \%$ trypsin were seeded into the upper chambers of inserts at a density of $4.5 \times 10^{4}$ in $100 \mu 1$. The lower chambers were filled with pre-warmed culture medium containing hormones: FSH ( 1 or $10 \mathrm{U} / \mathrm{ml}), \mathrm{LH}$ (1 or $10 \mathrm{U} / \mathrm{ml})$, estrogen $(100 \mathrm{nM})$, progesterone $(100 \mathrm{nM})$, danazol $(80 \mu \mathrm{g} /$ $\mathrm{ml})$, or prolactin $(0.5 \mu \mathrm{g} / \mathrm{ml})$. Medium supplemented with $0.5 \%$ bovine serum albumin (BSA) was used as a negative control. After $24 \mathrm{~h}$, the inserts were removed from the Transwell supports. The cells that had not migrated were scraped off with cotton wool from the upper membrane, and the cells that had transmigrated to the lower side of the membrane were fixed and stained with Hema 3 fixative according to the manufacturer's protocol (Fisher Fisher Scientific) and counted on the lower side of the membrane using an inverted microscope. To address whether the observed increase in motility is a result of a chemotactic or a chemokinetic response, we performed a checkerboard assay in which FSH (10 U/ml), LH $(10 \mathrm{U} / \mathrm{ml})$, estrogen $(100 \mathrm{nM})$, progesterone $(100 \mathrm{nM})$, danazol $(80 \mu \mathrm{g} / \mathrm{ml})$, and prolactin $(0.5 \mu \mathrm{g} / \mathrm{ml})$ were added at the same time into the upper and the lower Transwell chambers.

Fibronectin adhesion assay. Ninety-six-well plates were coated with fibronectin $(10 \mu \mathrm{g} / \mathrm{ml})$ overnight at $4^{\circ} \mathrm{C}$ and blocked with $0.5 \% \mathrm{BSA}$ for $1 \mathrm{~h}$ before the experiment. Cells were made quiescent for $3 \mathrm{~h}$ with $0.5 \% \mathrm{BSA}$ in medium before incubation with hormones: FSH (1 or $10 \mathrm{U} / \mathrm{ml}), \mathrm{LH}$ (1 or $10 \mathrm{U} / \mathrm{ml})$, estrogen $(100 \mathrm{nM})$, progesterone $(100 \mathrm{nM})$, danazol $(80 \mu \mathrm{g} / \mathrm{ml})$ or prolactin $(0.5 \mu \mathrm{g} / \mathrm{ml})$. Subsequently, cell suspensions $\left(2 \times 10^{3} / 100 \mu \mathrm{l}\right)$ were added directly to 96 -well 
plates coated with fibronectin and incubated for $5 \mathrm{~min}$ at $37^{\circ} \mathrm{C}$ Following incubation, the plates were vigorously washed three times to remove non-adherent cells, and the adherent cells were counted using an inverted microscope.

Cell proliferation. Cells were grown in 24-well culture plates at an initial density of $1.5 \times 10^{4}$ cells/well. After $24 \mathrm{~h}$, the medium was changed to new medium supplemented with hormones: FSH ( 1 or $10 \mathrm{U} / \mathrm{ml}), \mathrm{LH}(1$ or $10 \mathrm{U} / \mathrm{ml})$, estrogen $(100 \mathrm{nM})$, progesterone $(100 \mathrm{nM})$, danazol $(80 \mu \mathrm{g} / \mathrm{ml})$ or prolactin $(0.5 \mu \mathrm{g} / \mathrm{ml})$. The medium with $0.5 \% \mathrm{BSA}$ was used as a control. The cell number was calculated at 24,48 and $72 \mathrm{~h}$ after the change of medium.

Phosphorylation of intracellular pathway proteins. The fusion-positive RMS cell line RH30 and the fusion-negative cell line JR were incubated overnight in RPMI medium containing low levels of BSA $(0.5 \%)$ to render the cells quiescent. After the cells were stimulated with hormones: FSH (1 or $10 \mathrm{U} / \mathrm{ml}), \mathrm{LH}$ (1 or $10 \mathrm{U} / \mathrm{ml})$, estrogen $(100 \mathrm{nM})$, progesterone $(100 \mathrm{nM})$, danazol $(80 \mu \mathrm{g} / \mathrm{ml})$, or prolactin $(0.5 \mu \mathrm{g} / \mathrm{ml})$ at $37^{\circ} \mathrm{C}$ for $5 \mathrm{~min}$, the cells were lysed for $10 \mathrm{~min}$ on ice in RIPA lysis buffer containing protease and phosphatase inhibitors (Santa Cruz Biotechnology). The extracted proteins were separated on a 4-12\% SDS-PAGE gel and transferred to a PVDF membrane. Phosphorylation of the serine/threonine kinase AKT (yielding phospho-AKT473) and p44/42 mitogen-activated kinase (yielding phospho-p44/42 MAPK) was detected by phosphospecific p44/42 MAPK mouse and AKT rabbit polyclonal antibodies (Cell Signaling Technology, Danvers, MA, USA) with HRP-conjugated goat anti-mouse and anti-rabbit secondary antibodies (Santa Cruz Biotechnology). Equal loading in the lanes was evaluated by stripping the blots and reprobing with anti-p42/44 MAPK monoclonal antibody (Cell Signaling Technology) and anti-AKT polyclonal antibody (Cell Signaling Technology). The membranes were developed with an enhanced chemiluminescence (ECL) reagent (Amersham Life Science, Arlington Heights, IL, USA), dried, and subsequently exposed to film (Hyperfilm; Amersham Life Science).

In vivo experiments with transplants of RMS cells into immunodeficient mice. This study was performed in accordance with the guidelines of the Animal Care and Use Committee and Guide for Care and Use of Laboratory Animals (Department of Health and Human Services, publication no. 86-23). To evaluate the in vivo metastatic behavior of RH30 cell lines incubated with FSH $(50 \mathrm{U} / \mathrm{ml})$ and $\mathrm{LH}(50 \mathrm{U} / \mathrm{ml})$, after pre-treatment and a washing step, cells were injected intravenously (i.v.; $2.5 \times 10^{6}$ per mouse) into SCID mice. Marrows, livers and lungs were removed $48 \mathrm{~h}$ after injection of these cells, and the presence of RMS cells (i.e., murine-human chimerism) was evaluated by the level of human $\alpha$-satellite DNA expression. Detection of human satellite and murine $\beta$-actin DNA levels was conducted using real-time PCR and an ABI Prism 7500 Sequence detection system. A 25- $\mu 1$ reaction mixture containing $12.5 \mu \mathrm{l}$ SYBR-Green PCR Master Mix, 100 ng DNA template, primers for $\alpha$-satellite DNA: (forward, 5'-ACCACTCTGTGTCCTTC GTTCG-3' and reverse, 5'-ACTGCGCTCTCAAAAGGAG TGT-3'; and the primers for $\beta$-actin DNA: forward, 5'-TTCAATTCCAACACTGTCCTGTCT-3' and reverse,
5'-CTGTGGAGTGAC TAAATGGAAACC-3') were used. The number of human cells present in the murine organs (the degree of chimerism) was calculated from the standard curve obtained by mixing different numbers of human cells with a constant number of murine cells.

Patient samples. RMS frozen primary tumor specimens (n=58) (26 PAX3-FOXO1-positive, 7 PAX7-FOXO1-positive and 25 fusion-negative) were used for microarray profiling. Total RNA was extracted from primary tumors using RNA STAT-60 reagent (Tel-Test Inc., Friendswood, TX, USA) in accordance with the manufacturer's instructions. These RNA samples were analyzed on Affymetrix GeneChip ${ }^{\circledR}$ Human Genome U133 Plus 2.0 Arrays at the University of Pennsylvania Microarray Core Facility. The expression array data was normalized and $\log _{2}$-transformed with the RMA (robus multiarray average) algorithm in the Bioconductor oligo-package. The expression levels of FSH-R and LH-R were calculated using probe sets 211201_at and 207240s_at, respectively.

Statistical analysis. All results are presented as mean \pm SD. Statistical analysis of the data was done using Student's t-test for unpaired samples, with $\mathrm{P}<0.05$ considered to indicate a statistically significant result.

\section{Results}

Human RMS cell lines express several sex hormone receptors. First, we performed RT-PCR studies to evaluate mRNA expression in three human fusion-positive (RH28, RH30 and RH41) as well as five human fusion-negative (JR, RD, RH18, RH36 and SMS-CTR) RMS cell lines. Fig. 1 shows that we were able to detect mRNA for several sex hormone receptors by conventional RT-PCR. All cell lines evaluated in the present study expressed follicle-stimulating hormone receptor (FSH-R), luteinizing hormone receptor (LH-R) and androgen receptor (AR). While the progesterone receptor (PRG-R) was expressed in all cell lines except the RH18 fusion-negative RMS cell line, the prolactin receptor (PRL-R) was not expressed in RH30 and SMS-CTR cells. Several RMS cells also expressed estrogen receptor alpha (ER- $\alpha$ ) and beta (ER- $\beta$ ). We also found that mRNA from human skeletal muscle cells expressed all the receptors except FSH-R, PRL-R and ER- $\beta$.

To confirm expression of sex hormone receptors at protein level we evaluated fusion positive RH30 and fusion negative RD cells for expression of FSHR, LHR, AR and ER at protein level by immunofluorescence staining (Fig. 2) and confirmed that these cells express sex hormone receptors.

Exposure to sex hormones induces motility and adhesion of cells in human RMS cell lines. Next, to evaluate whether sex hormones are functional in human RMS cell lines, we performed chemotaxis and cell adhesion assays. In Transwell chemotaxis assays, we employed sex hormones at the indicated low and high doses to test their chemotactic effect against fusion-positive (Fig. 3A) and fusion-negative (Fig. 3B) RMS cell lines. We found that, of all the sex hormones tested, the strongest chemotactic activity was observed for FSH and/or LH. Some of the cell lines, such as RH28, RD, JR and RH36, also responded to PRL, PRG, androgen and estrogen stimula- 


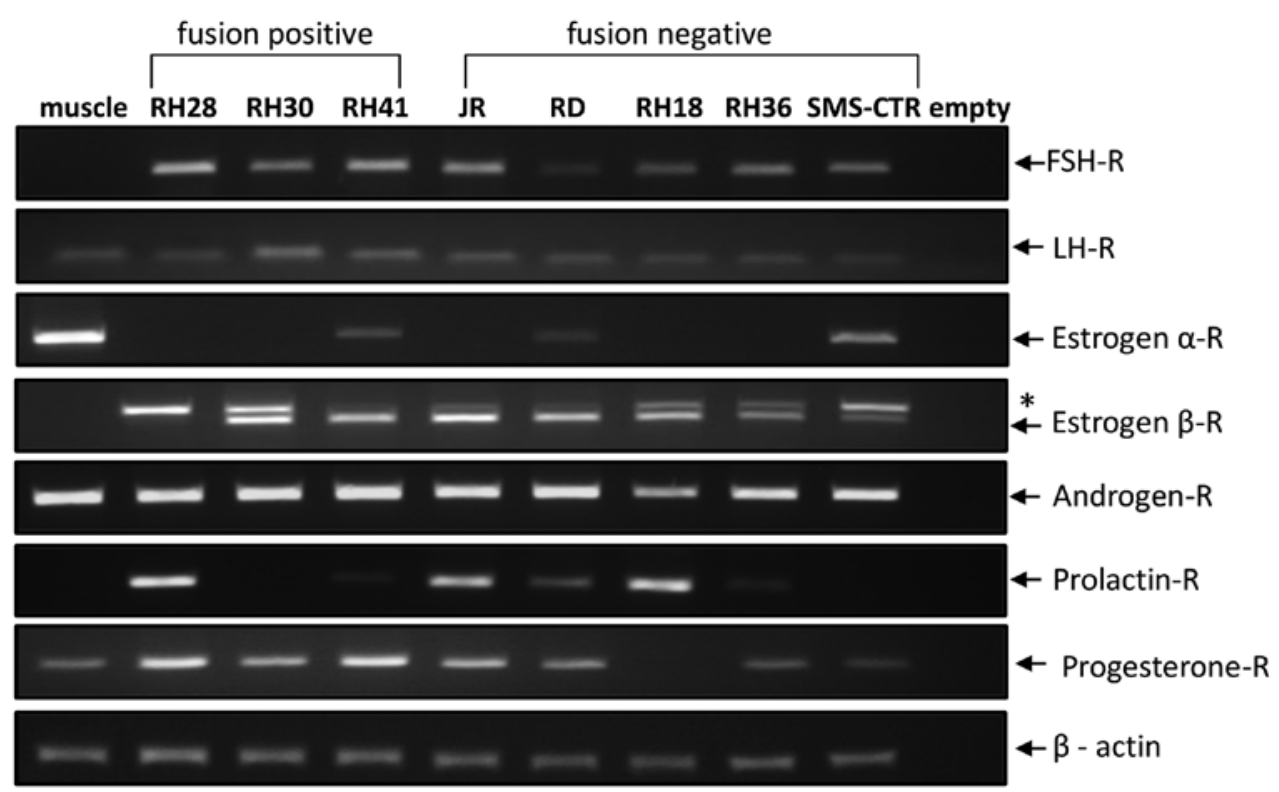

Figure 1. Sex hormone receptors are expressed in human rhabdomyosarcoma (RMS) cell lines. RT-PCR studies demonstrate sex hormone mRNA expression in three human fusion-positive (RH28, RH30 and RH41) and five human fusion-negative (JR, RD, RH18, RH36 and SMS-CTR) RMS cell lines. Normal skeletal muscle mRNA was used as a control. 'Empty' indicates samples in which water was used instead of template. The asterisk indicates non-coding isoform (upper band) of estrogen receptor $\beta$. The experiment was repeated three times with similar results. A representative gel image is shown.

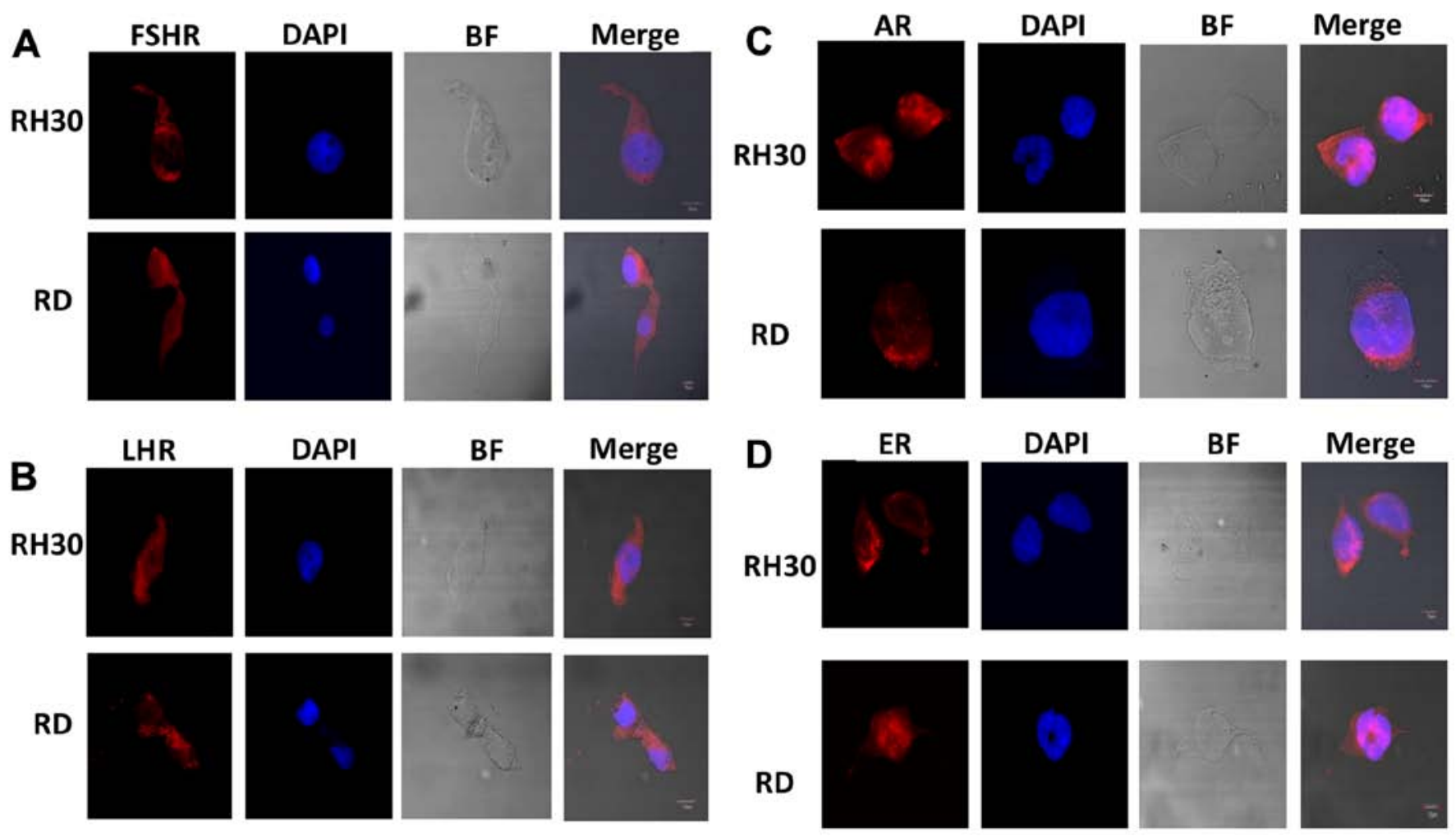

Figure 2. Human RMS cell lines express sex hormone receptors at protein level. Immunofluorescence staining of (A) FSH receptor, (B) LH receptor, androgen receptor (AR; C) and estrogen receptor (ER; D) in alveolar (RH30) and embryonal (RD) rhabdomyosarcoma. BL, bright field. Scale on merged picture indicate $10 \mu \mathrm{M}$.

tion. To address whether the observed effect of pituitary and gonaldal sex hormones on RMS cell motility was due to a chemotactic or chemokinetic effect, we performed a checkerboard assay (Fig. 4). We found that, while the effect of FSH and $\mathrm{LH}$ is both chemotactic and chemokinetic, the effect of PRL, PRG, androgen and estrogen is mostly chemokinetic.

Moreover, as in chemotaxis assays, our fusion-positive (Fig. 5A) and fusion-negative (Fig. 5B) human RMS cell lines 
A
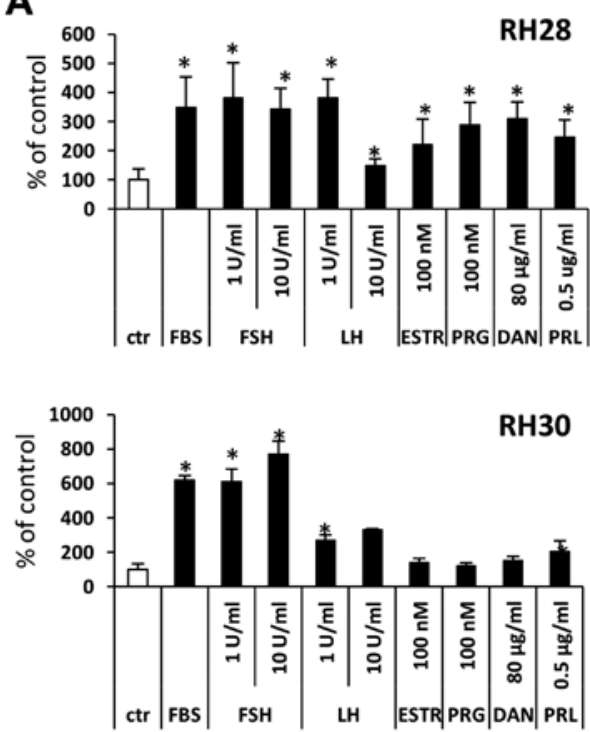

RH41

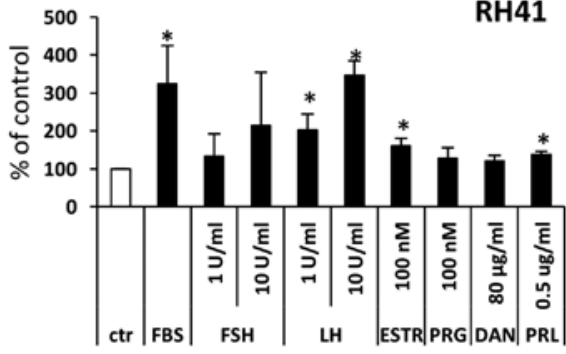

B
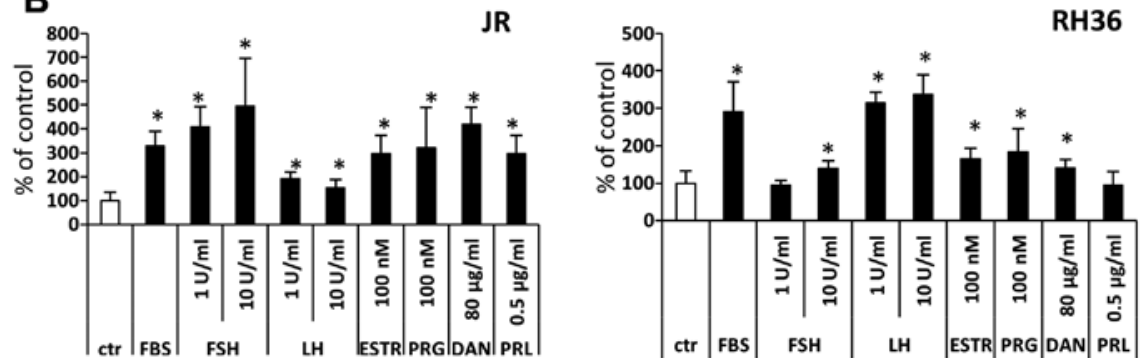

SMS-CTR
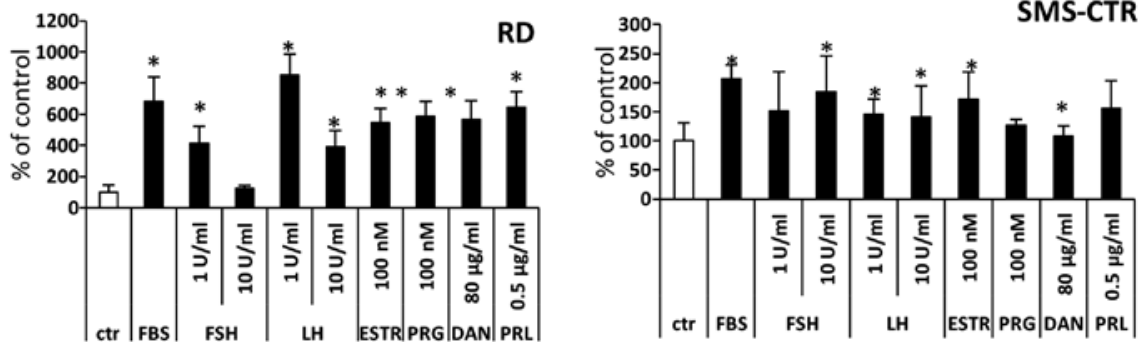

Figure 3. Sex hormones enhance migration of human RMS cell lines. The effect of sex hormones on the migration of fusion-positive (A) and fusion-negative (B) cells across Transwell membranes covered with gelatin. Medium with 10\% FBS was used as a positive control in chemotaxis assays. Combined results from three independent experiments are shown. $\mathrm{P} \leq 0.05$.

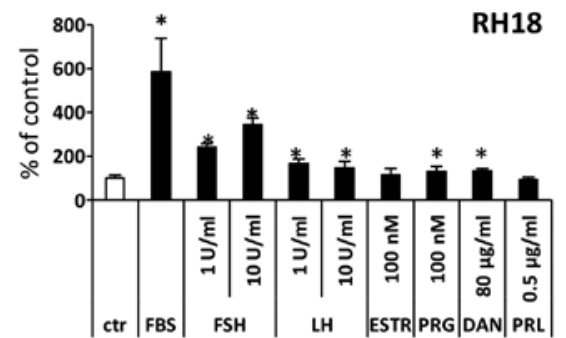

RH18
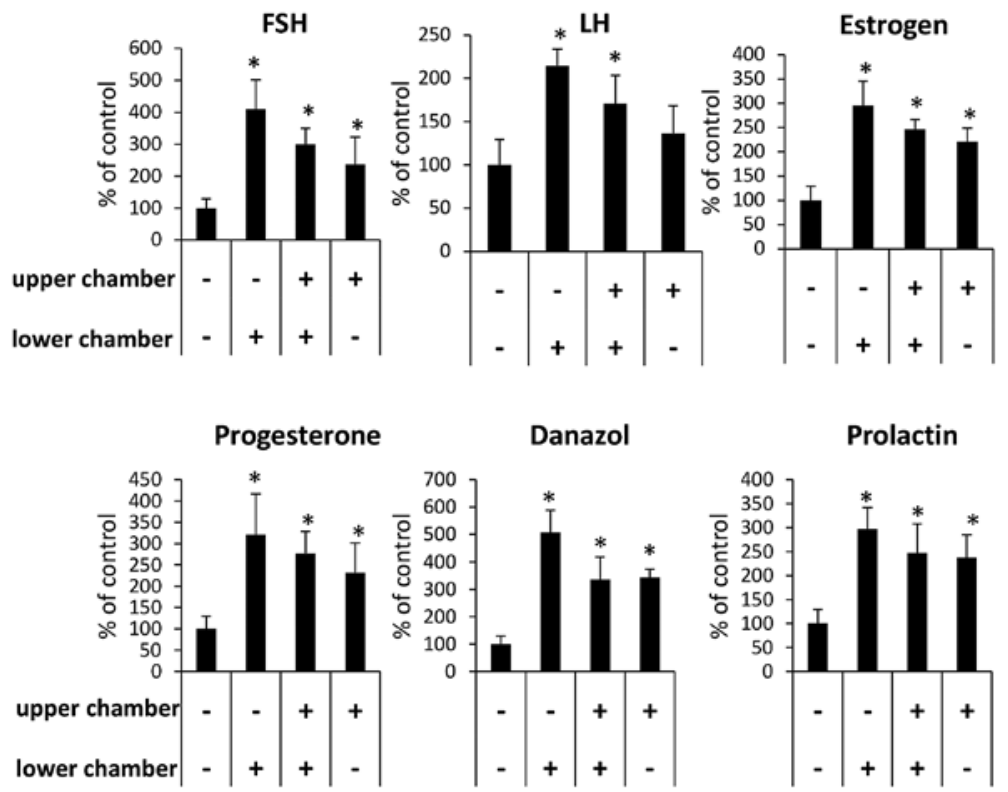

Figure 4. Sex hormone checkerboard assay for RH30 cell motility. Analysis of the effect of the presence of sex hormones in upper and/or lower chambers during the chemotaxis assay revealed that sex hormone stimulation of the motility of RH30 cells occurs mainly by chemokinesis. Data from three independent experiments are combined. $\mathrm{P} \leq 0.05$.

also responded to sex hormone stimulation in fibronectin adhesion assays. Finally, we became interested in whether prestimulation of RMS cells before injection into immunodeficient mice would affect their seeding efficiency to BM, liver 

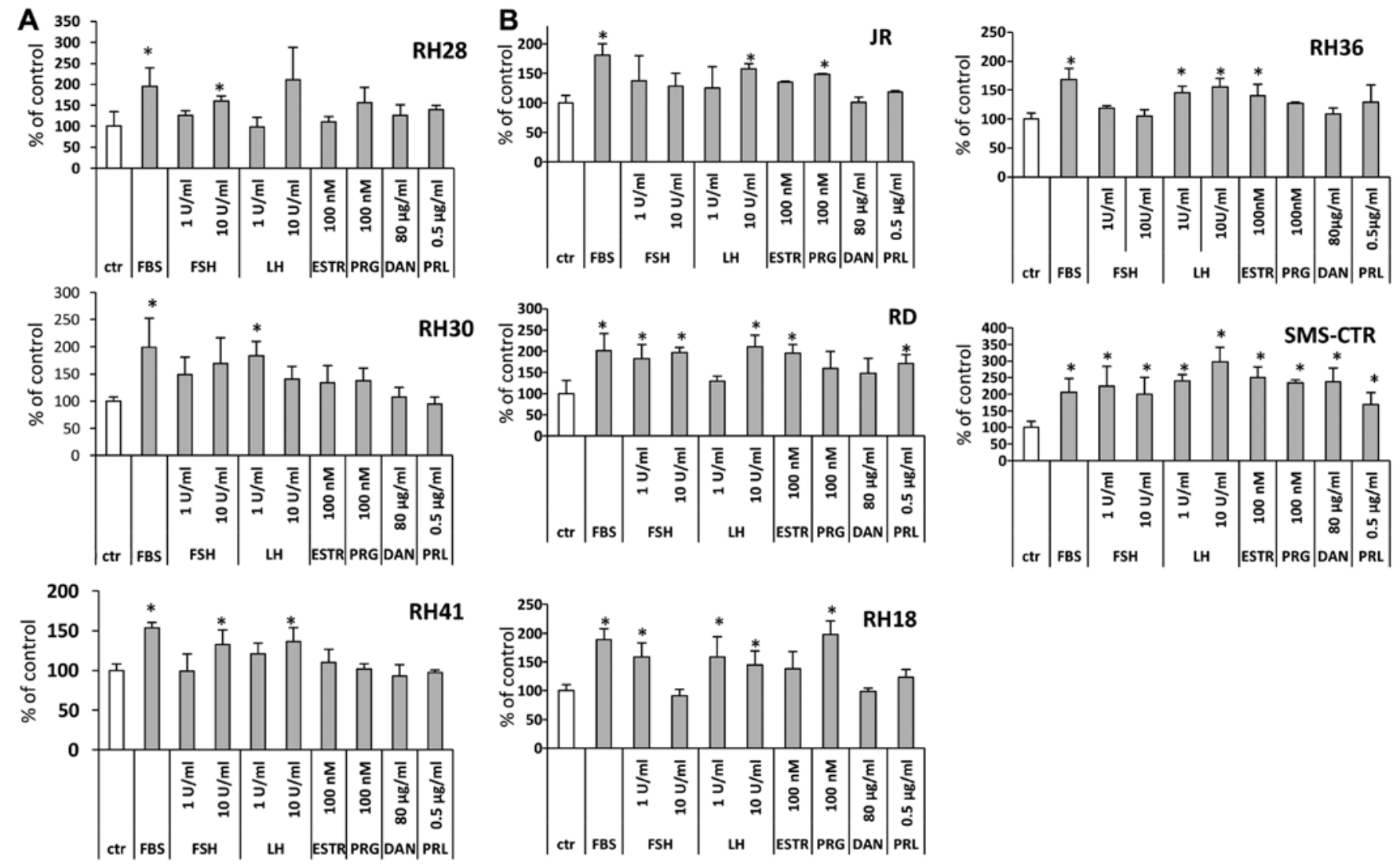

Figure 5. Stimulation of RMS cells with sex hormones enhances their adhesion to fibronectin. The effect of sex hormones on adhesion to fibronectin-coated dishes of fusion-positive (A) and fusion-negative (B) RMS cell lines. Combined results from three independent experiments are shown. * $\leq 0.05$.
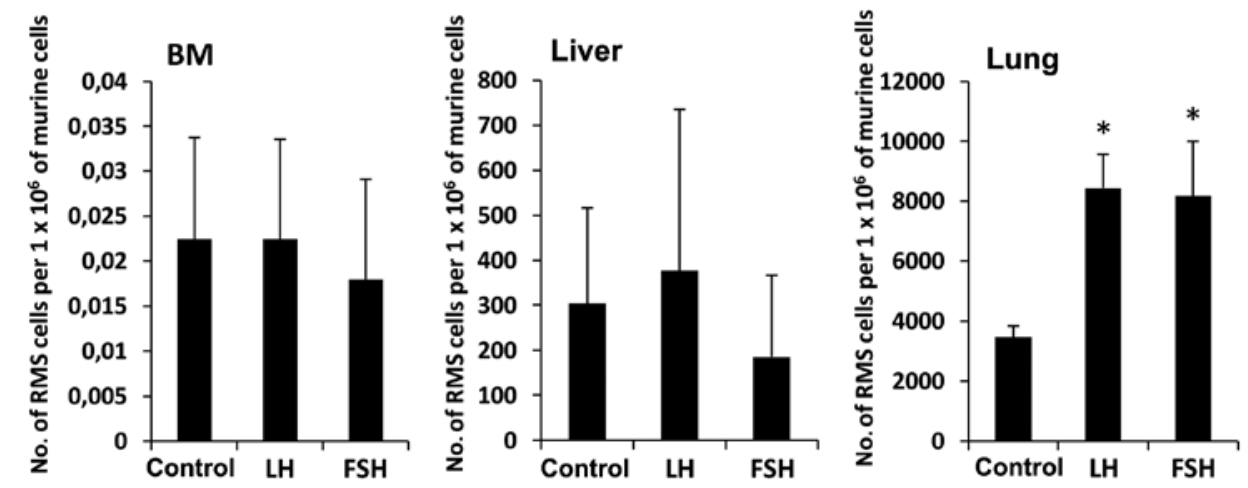

Figure 6. Effect of LH and FSH stimulation on the in vivo metastasis of RH30 cells. The number of RH30 cells was evaluated in lung, liver and bone marrow (BM) $48 \mathrm{~h}$ after i.v. injection of cells. The presence of human cells in murine tissues was evaluated as described in Materials and methods. Before injection, the cells were pretreated with LH or FSH. Data from two independent experiments are combined. "P $\leq 0.05$.

and lung. Fig. 6 shows that RH30 cells stimulated by FSH or LH had higher seeding efficiency into lung than control cells unstimulated by sex hormones.

Sex hormones induce proliferation of RMS cells. Sex hormones have been reported to stimulate proliferation of both normal and malignant cells. To evaluate the effect of sex hormones on RMS cell proliferation, we exposed fusion-positive (RH30) and fusion-negative (RD) cell lines in response to all pituitary and gonadal hormones evaluated in the present study. Figs. 7A and $8 \mathrm{~A}$ demonstrate that all of them stimulate proliferation of RMS cells. This positive pro-proliferation effect is supported by signal transduction studies that confirm that RMS cells express functional receptors for these hormones (Figs. 7B and $8 \mathrm{~B}$ ) and activate intracellular pathways potentially involved in cell proliferation, chemotaxis and adhesion.

Detection of $m R N A$ for pituitary sex hormone receptors FSH-R and LH-R in primary patient $R M S$ samples. Finally, we assessed FSH-R and LH-R expression by microarray analyses of 26 PAX3-FOXO1-positive, 7 PAX7-FOXO1-positive, and 25 fusion-negative patient samples. We chose these receptors, because we found that they exhibited the strongest responsiveness of our cell lines to FSH and LH stimulation. In all 

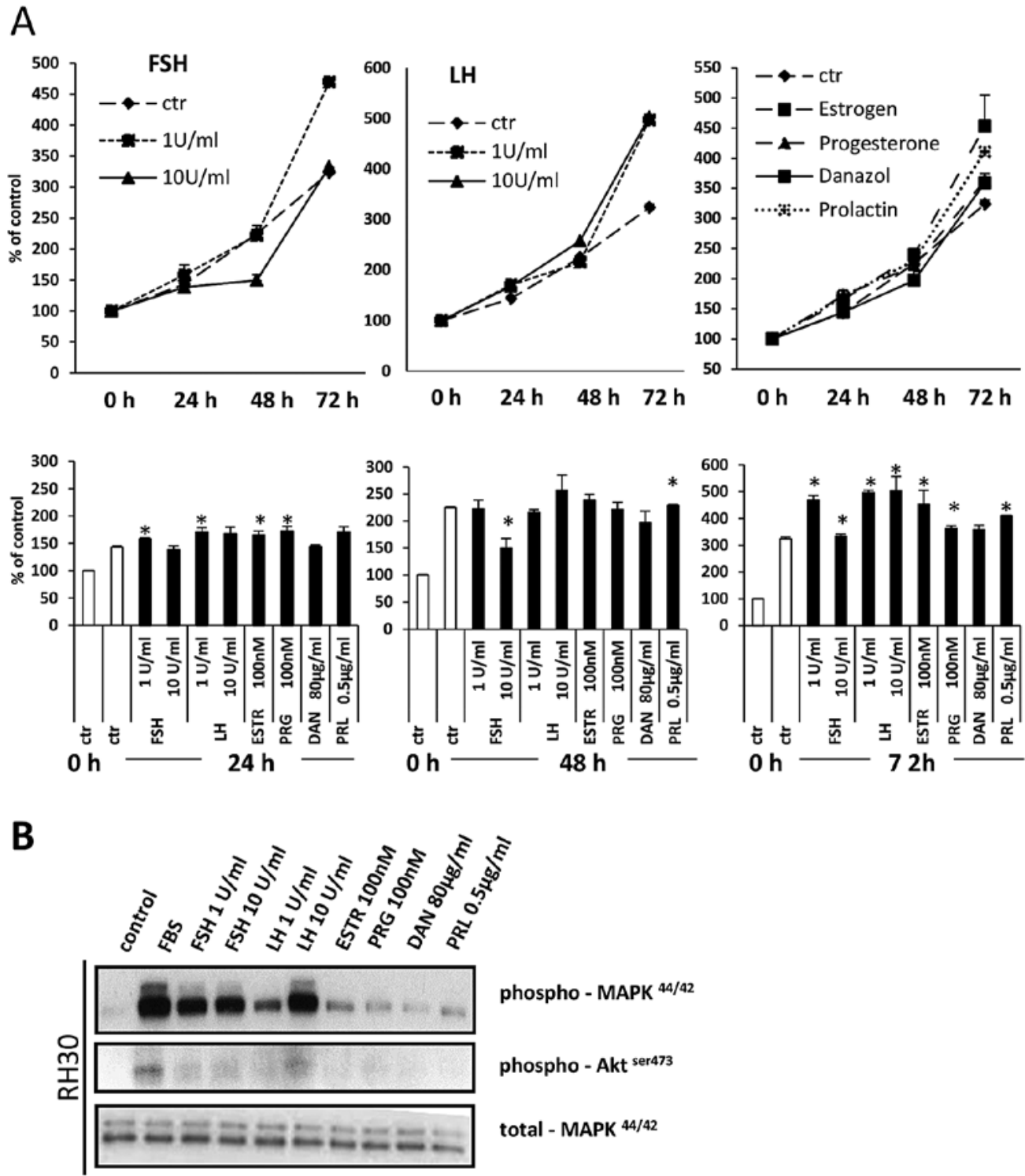

Figure 7. Sex hormones increase proliferation and induce signal transduction in fusion-positive RH30 cells. (A) Stimulation of fusion-positive RH30 cells with sex hormones increases their proliferation. Combined data from three independent experiments are shown; ${ }^{*} \mathrm{P} \leq 0.05$. (B) Effect of sex hormone activation of MAPKp42/44 and AKT. The experiment was performed twice, and a representative western blot analysis is shown.

these primary patient tumor samples, we were able to detect FSH-R and LH-R expression (Fig. 9A). However, we did not observe significant differences between fusion-positive RMS subtypes, PAX3-FOXO1 (FP-P3) and PAX7-FOXO1 (FP-P7) and fusion-negative subtypes.

\section{Discussion}

The salient observation of the present study is that human RMS cells express several pituitary and gonadal sex hormone receptors. Importantly, in assays employed in our studies these receptors were functional and stimulated migration, proliferation and adhesion of RMS cells.

Evidence has accumulated that sex hormones could be involved in pathogenesis of female and male gonadal tumors as well as breast and prostate cancer (21-23). In addition, non-gonadal tumors, including stomach, lung and liver cancer and melanomas, were also found to express sex hormone receptors (24-27). In addition, they express cancer testis anti- gens (CTA), which could indicate a potential developmental link between these tumors and the germ line-derived cells (28-31). Similarly, RMS cells were also reported to express CTA $(13,14)$. Rare cases of coexistence of RMS with adenocarcionoma have also been described in endometriotic cysts of the ovary (32) and with Mullerian adenosarcomas in the uterus (33). Interestingly, as we reported recently human and murine germline tumors and RMS cells share functional erythropoietin receptors (34).

RMS is a tumor in which cells share several characteristics with skeletal muscle cells, while, it is also well known that sex hormones regulate the development of skeletal muscles and play a role in their regeneration (9-11). Moreover, decrease in the level of sex hormones with age is responsible for the development of sarcopenia in $30 \%$ of individuals aged over 60 years $(35,36)$. Furthermore, results obtained from rodent models demonstrated that androgens and estrogens augment skeletal muscle satellite stem cell activation and modulate inflammatory processes during skeletal muscle regeneration $(9,12)$. 

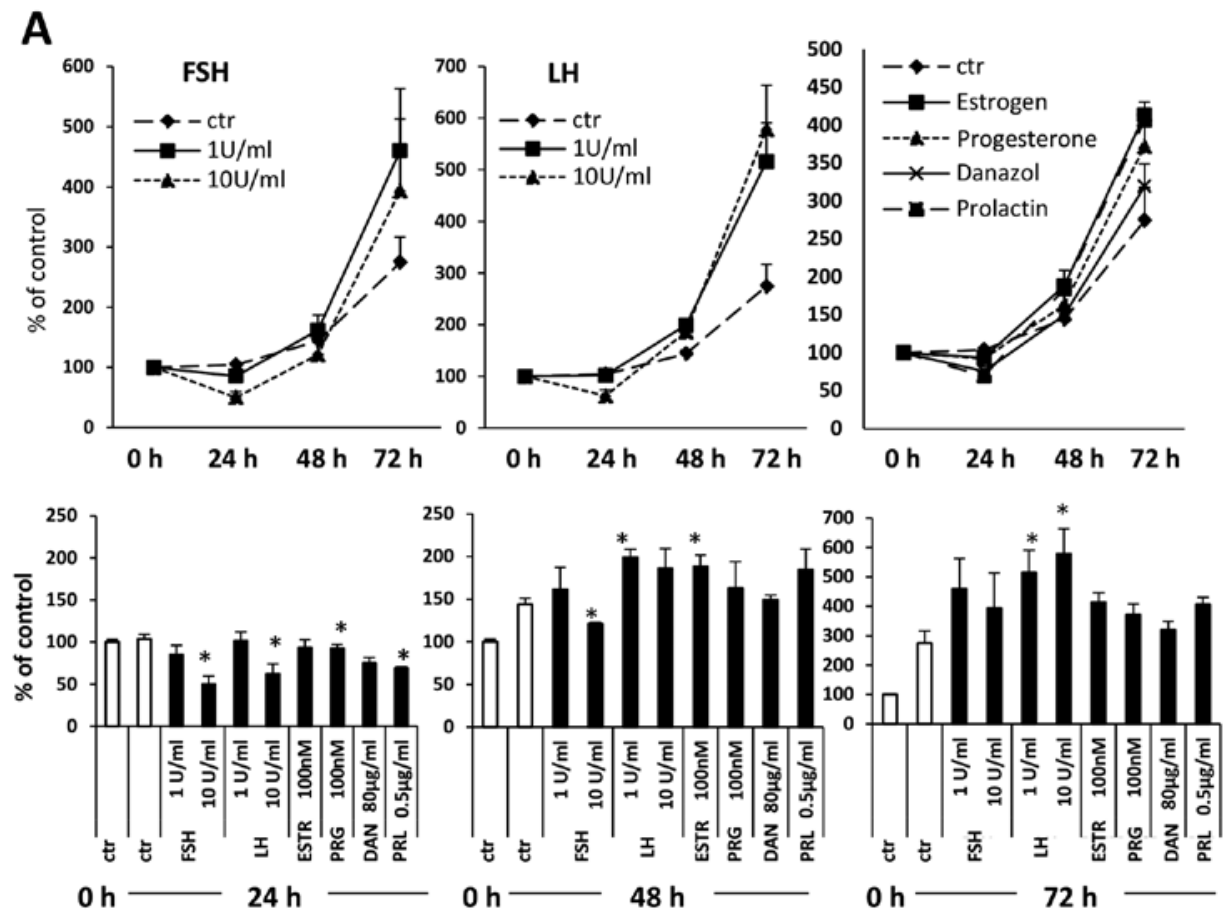

B

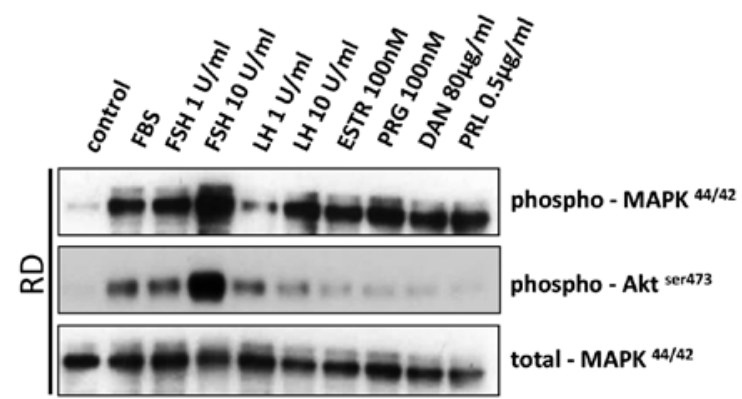

Figure 8. Sex hormones increase proliferation and induce signal transduction in fusion-negative RD cells. (A) Stimulation of fusion-negative RD cells with sex hormones increases their proliferation. Combined data from three independent experiments are shown. "P $\leq 0.05$. (B) Effect of sex hormones activation of MAPKp42/44 and AKT. Representative western blot analysis out of two performed is shown.
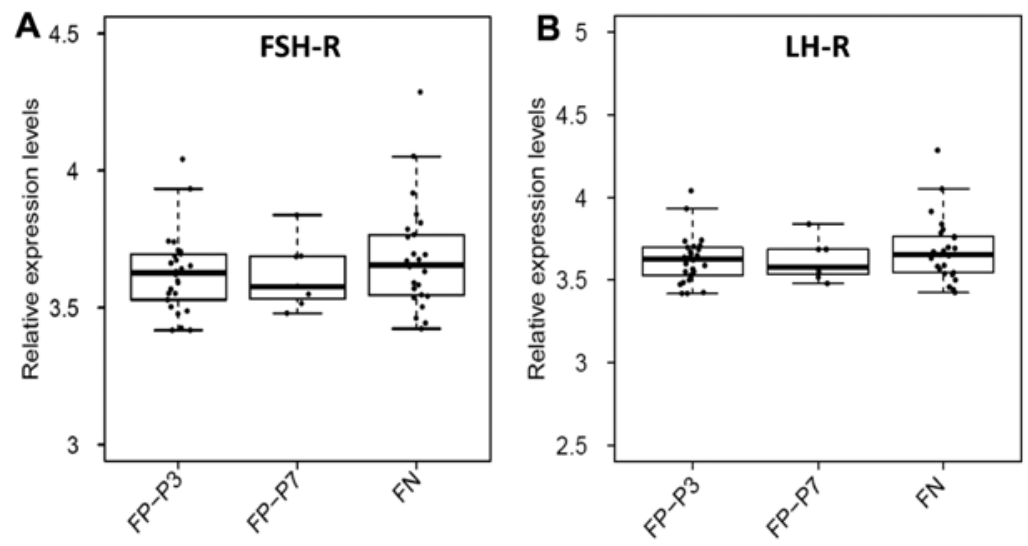

Figure 9. FSH and LH receptors mRNA expression in RMS tumors. Expression levels of FSH (A) LH (B) receptors were quantified by microarray in PAX3FOXO1-positive (FP-P3), PAX7-FOXO1-positive (FP-P7), and fusion-negative (FN) RMS samples. These values were then normalized and $\log _{2}$ transformed as described in Materials and methods. Boxes represent the interquartile range (25th-75th percentile) and horizontal lines inside the boxes indicate median. Whiskers indicate the minimum and maximum values, except for outliers.

Despite the fact that gonadal sex hormones affect expansion of skeletal muscle cells, very little is known about the role of gonadal and pituitary sex hormones in RMS pathogenesis. To shed more light on this process, we tested several established human RMS cell lines as well as primary patient samples for expression of functional sex hormone receptors. 
RMS is a tumor that mostly develops in children and young adults (3). Thus, an open question remains whether sex hormones are involved in RMS development at the levels observed in these patients. Our results clearly show that sex hormones stimulate proliferation and regulate motility of RMS cells. Expression of their receptors was detectable in established human cell lines as well as in primary patient samples. The presence of these receptors on RMS cells suggests that in particular pituitary sex hormone therapy in RMS survivors may lead to reactivation of 'dormant' malignant cells. In fact, recurrence of RMS in young women 25 years after estrogen and progesterone therapy has been reported (37). The tumor appeared 3 months after commencing hormonal therapy, and primary and recurrent tumors were immunohistochemically identical (37). Notably, our observation here that both androgen and estrogens simulate proliferation of RMS cells may explain why there is no significant sex-dependent predisposition for RMS development (38).

The recurrence of tumor growth after successful initial treatment and the fatal tendency of cancerous cells to spread and metastasize to different vital organs are major problems affecting the survival of cancer patients, including those afflicted with RMS (4). The tropism of cancer cells to metastasize to selected organs requires the involvement of organ-specific factors that direct metastasis. These factors promote the formation of a pre-metastatic niche that provides metastasizing tumor cells with a favorable growth and survival environment $(39,40)$. An important step in the metastatic process is egress of cancer cells from the primary tumor (41). This egress could be the result of random motility of cancer cells, a process known as chemokinesis, or the result of directed gradient-mediated migration, known as chemotaxis (42). Our results indicate that both processes, chemokinesis and chemotaxis, occur in RMS cells upon stimulation by sex hormones, and, for the first time, we identified them as a potential prometastatic factors for RMS cells. The metastasis of RMS cells, however, is directed by several other factors, including growth factors (e.g., hepatocyte growth factor and insulin-like growth factors 1 and 2) (43-45) chemokines (stromal-derived factor 1 alpha, and macrophage inhibitory factor) $(46,47)$, cytokines (leukemia inhibitory factor) (48), as well as several bioactive lipids (sphingosine-1-phosphate, ceramide-1-phosphate-1 (49), lysophosphatidylocholine and lysophosphatidic acid) (50). Since sex hormones increase the motility of RMS cells, they may promote their egress from the primary tumor and direct their spread to distant locations. Further work is also needed to address their cooperative, pro-metastatic effect in combination with other pro-metastatic factors.

It is known that pituitary and gonadal sex hormone receptors are expressed by cells from the germ lineage beginning at the very early stages of embryogenesis $(51,52)$. As demonstrated in this study, RMS cells also express receptors both for pituitary peptide and gonadal steroid sex hormones. Interestingly, as mentioned above, Virchow (18) and Connheim (19) proposed that some malignancies develop from dormant embryonic or germ cells residing in adult tissues. We have recently reported the existence of very small embryonic-like stem cells (VSELs), which express several embryonic/germline markers residing in adult tissues, including skeletal muscle (53). One can speculate that these or closely related cells could theoretically be the source of some tumors, including pediatric sarcomas. In support of this possibility, VSELs express several sex hormone receptors (54) as well as genes involved in primordial germ cells and skeletal muscle development $(53,55)$. This interesting hypothesis, however, requires more experimental evidence.

In conclusion, the presence of functional sex hormone receptors in RMS cells indicates that sex hormone supplementation, e.g., in RMS survivors, may result in the unwanted side-effect of tumor recurrence. Finally, like the expression of CTA antigens $(13,14)$, the presence of functional sex hormone receptors in RMS cells is consistent with the hypothesis that some pediatric sarcomas could develop in adult tissues from embryonic remnants that are endowed with germline potential.

\section{Acknowledgements}

We would like to thank Dr Sylwia Rzeszotek from Pomeranian Medical University for her help with immunofluorescence staining. The present study was supported by the NIH grants 2R01 DK074720 and R01HL112788, the Stella and Henry Endowment, the Maestro grant 2011/02/A/NZ4/00035 and the NCN Harmonia Grant UMO-2014/14/M/NZ3/00475 to M.Z.R. The work by F.G.B. and W.S. was supported by the Intramural Research Program of the National Cancer Institute.

\section{References}

1. Gurney JG, Severson RK, Davis S and Robison LL: Incidence of cancer in children in the United States. Sex-, race-, and 1-year age-specific rates by histologic type. Cancer 75: 2186-2195, 1995.

2. Huh WW and Skapek SX: Childhood rhabdomyosarcoma: New insight on biology and treatment. Curr Oncol Rep 12: 402-410, 2010.

3. Sultan I, Qaddoumi I, Yaser S, Rodriguez-Galindo C and Ferrari A: Comparing adult and pediatric rhabdomyosarcoma in the surveillance, epidemiology and end results program, 1973 to 2005: An analysis of 2,600 patients. J Clin Oncol 27: 3391-3397, 2009.

4. Sandberg AA, Stone JF, Czarnecki L and Cohen JD: Hematologic masquerade of rhabdomyosarcoma. Am J Hematol 68: 51-57, 2001.

5. Newton WA Jr, Gehan EA, Webber BL, Marsden HB, van Unnik AJ, Hamoudi AB, Tsokos MG, Shimada H, Harms D, Schmidt D, et al: Classification of rhabdomyosarcomas and related sarcomas. Pathologic aspects and proposal for a new classification - an Intergroup Rhabdomyosarcoma Study. Cancer 76: 1073-1085, 1995

6. Davis RJ, D'Cruz CM, Lovell MA, Biegel JA and Barr FG: Fusion of PAX7 to FKHR by the variant $\mathrm{t}(1 ; 13)(\mathrm{p} 36 ; \mathrm{q} 14)$ translocation in alveolar rhabdomyosarcoma. Cancer Res 54: 2869-2872, 1994.

7. Collins MH, Zhao H, Womer RB and Barr FG: Proliferative and apoptotic differences between alveolar rhabdomyosarcoma subtypes: A comparative study of tumors containing PAX3-FKHR or PAX7-FKHR gene fusions. Med Pediatr Oncol 37: 83-89, 2001.

8. Kashi VP, Hatley ME and Galindo RL: Probing for a deeper understanding of rhabdomyosarcoma: Insights from complementary model systems. Nat Rev Cancer 15: 426-439, 2015.

9. MacKrell JG, Yaden BC, Bullock H, Chen K, Shetler P, Bryant HU and Krishnan V: Molecular targets of androgen signaling that characterize skeletal muscle recovery and regeneration. Nucl Recept Signal 13: e005, 2015.

10. Carson JA and Manolagas SC: Effects of sex steroids on bones and muscles: Similarities, parallels, and putative interactions in health and disease. Bone 80: 67-78, 2015.

11. Velders $M$ and Diel P: How sex hormones promote skeletal muscle regeneration. Sports Med 43: 1089-1100, 2013.

12. Reiter BC, Kamanga-Sollo E, Pampusch MS, White ME and Dayton WR: Epidermal growth factor receptor is required for estradiol-stimulated bovine satellite cell proliferation. Domest Anim Endocrinol 48: 48-55, 2014.

13. Dalerba P, Frascella E, Macino B, Mandruzzato S, Zambon A, Rosolen A, Carli M, Ninfo V and Zanovello P: MAGE, BAGE and GAGE gene expression in human rhabdomyosarcomas. Int $\mathrm{J}$ Cancer 93: 85-90, 2001 
14. Lifantseva N, Koltsova A, Krylova T, Yakovleva T, Poljanskaya G and Gordeeva O: Expression patterns of cancer-testis antigens in human embryonic stem cells and their cell derivatives indicate lineage tracks. Stem Cells Int 2011: 795239, 2011.

15. Anderson J, Gordon A, McManus A, Shipley J and PritchardJones K: Disruption of imprinted genes at chromosome region 11p15.5 in paediatric rhabdomyosarcoma. Neoplasia 1: 340-348, 1999.

16. Roeb W, Boyer A, Cavenee WK and Arden KC: PAX3-FOXO1 controls expression of the p57Kip2 cell-cycle regulator through degradation of EGR1. Proc Natl Acad Sci USA 104: 18085-18090, 2007.

17. Schneider G, Bowser MJ, Shin DM, Barr FG and Ratajczak MZ: The paternally imprinted DLK1-GTL2 locus is differentially methylated in embryonal and alveolar rhabdomyosarcomas. Int J Oncol 44: 295-300, 2014

18. Virchow R: Editorial Archive fuer pathologische. Anatomie und Physiologie fuer klinische Medizin 8: 23-54, 1855 (In German).

19. Conheim J: Congenitales, quergestreiftes muskelsarkon der nireren. Virchows Arch 65: 64-69, 1875 (In German).

20. Aloisio GM, Nakada Y, Saatcioglu HD, Peña CG, Baker MD, Tarnawa ED, Mukherjee J, Manjunath H, Bugde A, Sengupta AL, et al: PAX7 expression defines germline stem cells in the adult testis. J Clin Invest 124: 3929-3944, 2014.

21. van Kruchten M, van der Marel P, de Munck L, Hollema H, Arts H, Timmer-Bosscha H, de Vries E, Hospers G and Reyners A: Hormone receptors as a marker of poor survival in epithelial ovarian cancer. Gynecol Oncol 138: 634-639, 2015.

22. Lønning PE: Poor-prognosis estrogen receptor- positive disease: Present and future clinical solutions. Ther Adv Med Oncol 4: $127-137,2012$

23. García-Cruz E, Piqueras M, Huguet J, Peri L, Izquierdo L, Musquera M, Franco A, Alvarez-Vijande R, Ribal MJ and Alcaraz A: Low testosterone levels are related to poor prognosis factors in men with prostate cancer prior to treatment. BJU Int 110: E541-E546, 2012.

24. Ryu WS, Kim JH, Jang YJ, Park SS, Um JW, Park SH, Kim SJ, Mok YJ and Kim CS: Expression of estrogen receptors in gastric cancer and their clinical significance. J Surg Oncol 106: 456-461, 2012.

25. Wang AG, Lee KY, Kim SY, Choi JY, Lee KH, Kim WH, Wang HJ, Kim JM, Park MG, Yeom YI, et al: The expression of estrogen receptors in hepatocellular carcinoma in Korean patients. Yonsei Med J 47: 811-816, 2006.

26. Siegfried JM, Hershberger PA and Stabile LP: Estrogen receptor signaling in lung cancer. Semin Oncol 36: 524-531, 2009.

27. Zhou JH, Kim KB, Myers JN, Fox PS, Ning J, Bassett RL, Hasanein $\mathrm{H}$ and Prieto VG: Immunohistochemical expression of hormone receptors in melanoma of pregnant women, nonpregnant women, and men. Am J Dermatopathol 36: 74-79, 2014.

28. Nakamura Y, Tanaka F, Nagahara H, Ieta K, Haraguchi $N$, Mimori K, Sasaki A, Inoue H, Yanaga K and Mori M: Opa interacting protein 5 (OIP5) is a novel cancer-testis specific gene in gastric cancer. Ann Surg Oncol 14: 885-892, 2007.

29. Song MH, Choi KU, Shin DH, Lee CH and Lee SY: Identification of the cancer/testis antigens AKAP3 and CTp11 by SEREX in hepatocellular carcinoma. Oncol Rep 28: 1792-1798, 2012.

30. Su C, Xu Y, Li X, Ren S, Zhao C, Hou L, Ye Z and Zhou C: Predictive and prognostic effect of CD133 and cancer-testis antigens in stage Ib-IIIA non-small cell lung cancer. Int J Clin Exp Pathol 8: 5509-5518, 2015.

31. Sigalotti L, Fratta E, Coral S, Tanzarella S, Danielli R, Colizzi F, Fonsatti E, Traversari C, Altomonte $\mathrm{M}$ and Maio M: Intratumor heterogeneity of cancer/testis antigens expression in human cutaneous melanoma is methylation-regulated and functionally reverted by 5-aza-2'-deoxycytidine. Cancer Res 64: 9167-9171, 2004

32. Yasuoka H, Tsujimoto M, Fujita S, Yamasaki T, Kashihara H, Nishio Y, Kodama R, Inagaki M, Oishi H, Sanke T, et al: Coexistence of a clear cell adenocarcinoma and an adenosarcoma with a heterologous rhabdomyosarcoma in an endometriotic cyst of the ovary: A case study. Int J Gynecol Pathol 28: 362-366, 2009

33. Kim DW, Shin JH, Lee HJ, Hong YO, Joo JE and Kim EK Spindle cell rhabdomyosacoma of uterus: A case study. Korean J Pathol 47: 388-391, 2013.

34. Poniewierska-Baran A, Suszynska M, Sun W, AbdelbasetIsmail A, Schneider G, Barr FG and Ratajczak MZ: Human rhabdomyosarcoma cells express functional erythropoietin receptor: Potential therapeutic implications. Int J Oncol 47: 1989-1997, 2015.
35. Kamel HK, Maas D and Duthie EH Jr: Role of hormones in the pathogenesis and management of sarcopenia. Drugs Aging 19: $865-877,2002$

36. Baumgartner RN, Koehler KM, Gallagher D, Romero L, Heymsfield SB, Ross RR, Garry PJ and Lindeman RD: Epidemiology of sarcopenia among the elderly in New Mexico. Am J Epidemiol 147: 755-763, 1998

37. Zacharin M, Waters K, Chow CW, Crock P and McKelvie P: Recurrent rhabdomyosarcoma after 25 years: A possible association with estrogen and progestogen therapy. J Pediatr Hematol Oncol 19: 477-481, 1997.

38. Dagher R and Helman L: Rhabdomyosarcoma: An overview. Oncologist 4: 34-44, 1999.

39. Nguyen DX, Bos PD and Massagué J: Metastasis: From dissemination to organ-specific colonization. Nat Rev Cancer 9: 274-284, 2009.

40. Zlotnik A, Burkhardt AM and Homey B: Homeostatic chemokine receptors and organ-specific metastasis. Nat Rev Immunol 11: 597-606, 2011.

41. Coghlin C and Murray GI: Current and emerging concepts in tumour metastasis. J Pathol 222: 1-15, 2010.

42. Petrie RJ, Doyle AD and Yamada KM: Random versus directionally persistent cell migration. Nat Rev Mol Cell Biol 10: 538-549, 2009.

43. Jankowski K, Kucia M, Wysoczynski M, Reca R, Zhao D, Trzyna E, Trent J, Peiper S, Zembala M, Ratajczak J, et al: Both hepatocyte growth factor (HGF) and stromal-derived factor-1 regulate the metastatic behavior of human rhabdomyosarcoma cells, but only HGF enhances their resistance to radiochemotherapy. Cancer Res 63: 7926-7935, 2003.

44. Kalebic T, Tsokos $M$ and Helman LJ: In vivo treatment with antibody against IGF-1 receptor suppresses growth of human rhabdomyosarcoma and down-regulates p34cdc2. Cancer Res 54: 5531-5534, 1994.

45. Rezvani G, Lui JC, Barnes KM and Baron J: A set of imprinted genes required for normal body growth also promotes growth of rhabdomyosarcoma cells. Pediatr Res 71: 32-38, 2012.

46. Libura J, Drukala J, Majka M, Tomescu O, Navenot JM, Kucia M, Marquez L, Peiper SC, Barr FG, Janowska-Wieczorek A, et al: CXCR4-SDF-1 signaling is active in rhabdomyosarcoma cells and regulates locomotion, chemotaxis, and adhesion. Blood 100 2597-2606, 2002

47. Tarnowski M, Grymula K, Liu R, Tarnowska J, Drukala J, Ratajczak J, Mitchell RA, Ratajczak MZ and Kucia M: Macrophage migration inhibitory factor is secreted by rhabdomyosarcoma cells, modulates tumor metastasis by binding to CXCR4 and CXCR7 receptors and inhibits recruitment of cancerassociated fibroblasts. Mol Cancer Res 8: 1328-1343, 2010.

48. Wysoczynski M, Miekus K, Jankowski K, Wanzeck J, Bertolone S, Janowska-Wieczorek A, Ratajczak J and Ratajczak MZ: Leukemia inhibitory factor: A newly identified metastatic factor in rhabdomyosarcomas. Cancer Res 67: 2131-2140, 2007.

49. Schneider G, Bryndza E, Abdel-Latif A, Ratajczak J, Maj M, Tarnowski M, Klyachkin YM, Houghton P, Morris AJ, Vater A, et al: Bioactive lipids S1P and C1P are prometastatic factors in human rhabdomyosarcoma, and their tissue levels increase in response to radio/chemotherapy. Mol Cancer Res 11: 793-807, 2013.

50. Schneider G, Sellers ZP, Abdel-Latif A, Morris AJ and RatajczakMZ: Bioactive lipids, LPC and LPA, are novel prometastatic factors and their tissue levels increase in response to radio/chemotherapy. Mol Cancer Res 12: 1560-1573, 2014.

51. Hou Q and Gorski J: Estrogen receptor and progesterone receptor genes are expressed differentially in mouse embryos during preimplantation development. Proc Natl Acad Sci USA 90: 9460-9464, 1993.

52. Crocoll A, Zhu CC, Cato AC and Blum M: Expression of androgen receptor mRNA during mouse embryogenesis. Mech Dev 72: 175-178, 1998.

53. Ratajczak MZ,Zuba-SurmaEK, Wysoczynski M, Ratajczak J and Kucia M: Very small embryonic-like stem cells: Characterization, developmental origin, and biological significance. Exp Hematol 36: 742-751, 2008

54. Mierzejewska K, Borkowska S, Suszynska E, Suszynska M, Poniewierska-Baran A, Maj M, Pedziwiatr D, Adamiak M, AbdelLatif A, Kakar SS, et al: Hematopoietic stem/progenitor cells express several functional sex hormone receptors-novel evidence for a potential developmental link between hematopoiesis and primordial germ cells. Stem Cells Dev 24: 927-937, 2015.

55. Zuba-Surma EK, Kucia M, Wu W, Klich I, Lillard JW Jr, Ratajczak J and Ratajczak MZ: Very small embryonic-like stem cells are present in adult murine organs: ImageStream-based morphological analysis and distribution studies. Cytometry A 73A: 1116-1127, 2008 